\title{
The effect of acetaminophen nanoparticles on liver toxicity in a rat model
}

This article was published in the following Dove Press journal:

International Journal of Nanomedicine

26 March 2010

Number of times this article has been viewed

\author{
Esmaeil Biazar' \\ S Mahdi Rezayat ${ }^{2}$ \\ Naser Montazeri' \\ Khalil Pourshamsian' \\ Reza Zeinali ${ }^{3}$ \\ Azadeh Asefnejad ${ }^{3}$ \\ Mehdi Rahimi ${ }^{3}$ \\ Mohammadmajid Zadehzare ${ }^{3}$ \\ Mehran Mahmoudi ${ }^{3}$ \\ Rohollah Mazinani ${ }^{3}$ \\ Mehdi Ziaei ${ }^{3}$ \\ 'Department of Chemistry, Islamic \\ Azad University, Tonekabon Branch, \\ Mazandaran, Iran; ${ }^{2}$ Department of \\ Pharmacology, School of Medicine, \\ Tehran University of Medical Science, \\ Tehran, Iran; ${ }^{3}$ Biomedical Engineering, \\ Islamic Azad University, Research and \\ Science Branch, Tehran, Iran
}

Correspondence: Esmaeil Biazar Islamic Azad University, Tonekabon Branch, Mazandaran, Iran

Tel +98 1924274415

Fax +98 I9 242744 II

Email e.biazar@tonekaboniau.ac.ir

\begin{abstract}
Acetaminophen, a pain-reliever, is one of the most widely used medications in the world. Acetaminophen with normal dosage is considered a nontoxic drug for therapeutic applications, but when taken at overdose levels it produces liver damage in human and various animal species. By a high energy mechanically activated method, we produced acetaminophen in a nanometer crystalline size $(24 \mathrm{~nm})$. Forty-eight hours after injection of crystalline particles with normal and reduced size of our drug, the effect of liver toxicity was compared by determination of liver transferase enzymes such as alkaline phosphatase, aspartate aminotransferase, and alanine aminotransferase (ALT). These enzymes were examined by routine colorimetric methods using commercial kits and pathologic investigations. Statistical analysis and pathological figures indicated that ALT delivery and toxicity in reduced size acetaminophen was significantly reduced when compared with normal size acetaminophen. Pathology figures exhibited reduced necrosis effects, especially the confluent necrosis, in the central part of the lobule in the reduced size acetaminophen samples when compared with the normal samples.
\end{abstract}

Keywords: acetaminophen, size reduction, pathological and enzymatic investigations, toxicity

\section{Introduction}

Nanotechnology consists of the study, control, and construction of nanosized materials $\left(10^{-9} \mathrm{~m}\right){ }^{1,2}$ The generation of nanoparticle drugs has created new perspectives in pharmacology. However it is essential to discover the properties of nanoparticles for the successful development of nanoparticle drugs. High pressure homogenization and supercritical fluid processing are technologies that are used today or are being developed for the generation of nanoparticles. ${ }^{3,4}$ Drug synthesis at the nanoscale commenced when interesting nanomaterial properties were discovered by their presence in particular areas of the human body. The employment of the mill was one of the first ideas for the transfer of the drug to the nanoscale. ${ }^{3-5}$ One of the methods for preparation of micro- and nanoparticles is mechanical activation. The actual process of mechanical alloying starts with mixing of the powders in the right proportion and loading the powder mix into the mill along with the grinding medium (generally steel balls). This mix is then milled for the desired length of time until a steady state is reached when the composition of every powder particle is proportional to the elements in the starting powder mix. Thus the important components of the mechanical alloying process are the raw materials, the mill, and the process variables. Particle size reduction, which increases the contact surface between particles, is the direct consequence of milling. When the energy of the system increases, mullitization temperatures decrease. ${ }^{6}$ 
Mechanical activation has become a phenomenon of general significance in pharmaceutics. Hüttenrauch and colleagues described the extent of activation induced by relevant processes ${ }^{7}$ and Haüsler studied the influence of mechanical activation on the physical stability of salbutamol sulfate. ${ }^{8}$

Acetaminophen $\left(\mathrm{C}_{8} \mathrm{H}_{9} \mathrm{NO}_{2}\right)$ is a crystalline white powder with a bitter taste, is odorless, and has a molecular weight of $151.16 .{ }^{9,10}$ About $90 \%$ of acetaminophen reacts with $30 \%$ sulphate and $60 \%$ glucuronide in the liver. These two metabolic pathways can be saturated. Some unmetabolized acetaminophen will be excreted through the kidney. Only a small amount of drug (maximum 15\% to $20 \%$ ) is changed to active metabolites through the mixed function of the kidney oxidase. In the presence of sufficient glutathione, this intermediate material is changed to mercapturic acid and cysteine and this function causes detoxification. A single dose of $800 \mathrm{mg} \mathrm{kgG} \mathrm{b.wt} \mathrm{caused} \mathrm{a} \mathrm{severe} \mathrm{hepatocellular}$ injury as indicated by a massive increase in serum alanine aminotransferase (ALT) activity and decreased plasma level of the parent acetaminophen.

Acetaminophen has poor solubility in water. It is well known that bioavailability of drugs with low solubility is often intrinsically related to drug particle size. The dissolution rate is reported to increase by one or more orders by reducing the magnitude of the drug particle and hence can lead to faster absorption rates. ${ }^{10}$ The main factor for this toxicity can be attributed to the toxic metabolite $\mathrm{N}$-acetyl-p-benzo-quinone imine (NAPQI) produced in the liver by changing a small percentage (about $5 \%-10 \%$ ) of the acetaminophen dose in the P450 cytochrome. ${ }^{11,12}$ In this condition, glutathione rapidly changes this toxic material to cysteine and mercapturate. Mercapturate is a stable metabolite that gradually leaves the body. The glutathione sources reduce progressively to its critical limit ( $30 \%$ of the abnormal source). As a consequence, mercapturate will not be able to neutralize NAPQI and this material will form a covalent bond with the cells, macromolecules, and the nucleus proteins of the liver, leading to necrosis of the central lobules. ${ }^{13,14}$ In this study, the size of the acetaminophen particles was reduced with the use of a mechanically activated dry mill and the effect of the reduced size on the liver toxicity was investigated with an overdose injection .

\section{Materials and methods}

\section{Materials and instruments}

Ball mill, spectrophotometer (NAVA speed; Nava Vadaj, Ahmedabad, India), a digital balance scale with $0.01 \%$ sensitivity (PM-4800; Mettler, Zürich, Switzerland), a precise balance scale with $0.0001 \mathrm{~g}$ (AE-200; Mettler), surgical blade, centrifuge, microplates of 10, 20, 50, and $100 \mu \mathrm{m}$ (Eppendorf, Hamburg, Germany) with a replaceable and disposable usable syringe, $5 \mathrm{~mL}$ pipettes, volumetric flask, $10 \mathrm{~mL}$ plastic laboratory tube, $500 \mu \mathrm{L}$ and $100 \mu \mathrm{L}$ samplers, acetaminophen powder with an average size of $1 \mu \mathrm{m}$ (Chimidarou Co, Tehran, Iran), formalin solution (10\% w/w), enzymatic kits (Emapol, Gdańsk, Poland), distilled water, ethanol, xyelen, dimethyl sulfoxide (DMSO) 20\% w/w, and paraffin.

\section{Methods}

The standard acetaminophen powder with an average size of $1 \mu \mathrm{m}$ and 1:15 weight ratio (ball to powder) were poured into the milling jar. The jar was mechanically activated for a short period of time. The sample was converted into a crystalline particle size of $24 \mathrm{~nm}$ with the mechanicallyactivated method.

The rats were kept for 24 hours without any food before the injection. This drug powder with an overdose of two different sizes ( $800 \mathrm{mg} \mathrm{kgG} \mathrm{b.wt)} \mathrm{with} \mathrm{a} \mathrm{DMSO} \mathrm{control}$ sample was intravenously injected into three groups of male rats $(n=7)$. Tissue samples were taken from their liver and placed into formalin solution. Small parts of this tissue were removed from the formalin solution and placed into the alcohol solution with an increasing percentage of solubility $(70 \%$, $80 \%, 90 \%$, and $100 \% \mathrm{w} / \mathrm{w}$ ). The samples were dehydrated. The tissue was placed into a xyelen solution after extracting all the alcohol used in dehydration step. Finally, the tissue became transparent. This procedure was performed automatically with tissue processor instrumentation. Afterwards, the samples were soaked into melting paraffin and the paraffin diffused completely into the tissue samples to form an internal mold. To generate external molds, we also used melting paraffin. After pouring paraffin on the tissue samples, they were placed into two L-shaped aluminum molds and kept in a cold environment to solidify the mold. The samples were cut into pieces of $3-5 \mu \mathrm{m}$.

The tissue samples were stained with hematoxylin and eosin to prepare them for microscopic examination. For the enzymatic investigation, drug powder with two different sized overdoses and a DMSO controller was intravenously injected in three groups of male rats. The rats were kept for 24 hours without any food before the injection. Blood samples were taken from all injected rats and then centrifuged. With the help of the alkaline phosphatase (ALP), ALT, aspartate aminotransferase (AST) enzyme recognition kits and the relative spectrometer functions, the relative numbers for the 
Table I The results of the injection of the normal acetaminophen samples into the liver

\begin{tabular}{ll}
\hline $\begin{array}{l}\text { Normal } \\
\text { acetaminophen }\end{array}$ & $\begin{array}{l}\text { Pathological results } \\
\text { of the liver tissue }\end{array}$ \\
\hline IL & $\begin{array}{l}\text { Infiltration of lymphocyte in the port, } \\
\text { piecemeal necrosis around the confluent } \\
\text { necrosis in the central part }\end{array}$ \\
\hline
\end{tabular}

enzymes were studied and analyzed. Student's $t$-test was used to estimate the differences.

\section{Results}

The pathological investigation on the liver tissue for the normal, control (DMSO), and reduced size acetaminophen samples were conducted. The corresponding results are presented in Tables 1, 2, and 3. 1L shows various liver tissue samples injected with normal acetaminophen samples. $2 \mathrm{~L}$ is related to the control samples, and $3 \mathrm{~L}$ is associated with the liver samples which have been injected with the reduced size acetaminophen samples.

Figures 1 and 2 display the pathological images of two liver tissue samples: i) the reduced size acetaminophen samples (24 nm); and ii) the normal size samples. Figure 1 is related to the reduced size acetaminophen samples (3L). In this liver sample, spotty necrosis around the central vein can be clearly identified. Figure 2 shows the normal size acetaminophen samples. In addition to the spotty necrosis, the confluent necrosis can also be observed around the central vein. Figure 2 shows the damage to the nucleuses and the cytoplasm.

In the enzymatic investigations, the AST, ALP, ALP enzyme activities and statistical estimations was estimated and evaluated with statistical significance of $P<0.05$. These results are listed in Table 4 and Figure 3.

\section{Conclusion}

In this study, a new method was introduced for determining the size reduction effect of acetaminophen particles from the average size of $1 \mu \mathrm{m}$ to $24 \mathrm{~nm}$. This reduction was achieved with the use of the mechanical activation and the enzyme effects on the liver toxicity of the rats

Table 2 The results of the injection of the control acetaminophen samples into the liver

\begin{tabular}{ll}
\hline Control & $\begin{array}{l}\text { Pathological results of the liver } \\
\text { tissue }\end{array}$ \\
\hline $2 \mathrm{~L}$ & $\begin{array}{l}\text { Slow infiltration of the lymphocyte in } \\
\text { the port }\end{array}$ \\
\hline
\end{tabular}

Table 3 The results of the injection of the reduced size acetaminophen samples into the liver

\begin{tabular}{ll}
\hline $\begin{array}{l}\text { Reduced size } \\
\text { acetaminophen }\end{array}$ & $\begin{array}{l}\text { Pathological results } \\
\text { of the liver tissue }\end{array}$ \\
\hline $3 \mathrm{~L}$ & $\begin{array}{l}\text { Infiltration of the lymphocyte in the } \\
\text { port, piece meal necrosis in the central } \\
\text { place, spotty necrosis }\end{array}$ \\
\hline
\end{tabular}

were compared. The results of the tissue samples in pathological investigations after the injection showed less complete spotty necrosis, especially in the confluent necrosis in the central lobule portion, for the reduced size acetaminophen samples when compared with the normal samples. We can infer that reduced size acetaminophen has lower effects on liver toxicity when compared with the normal one.
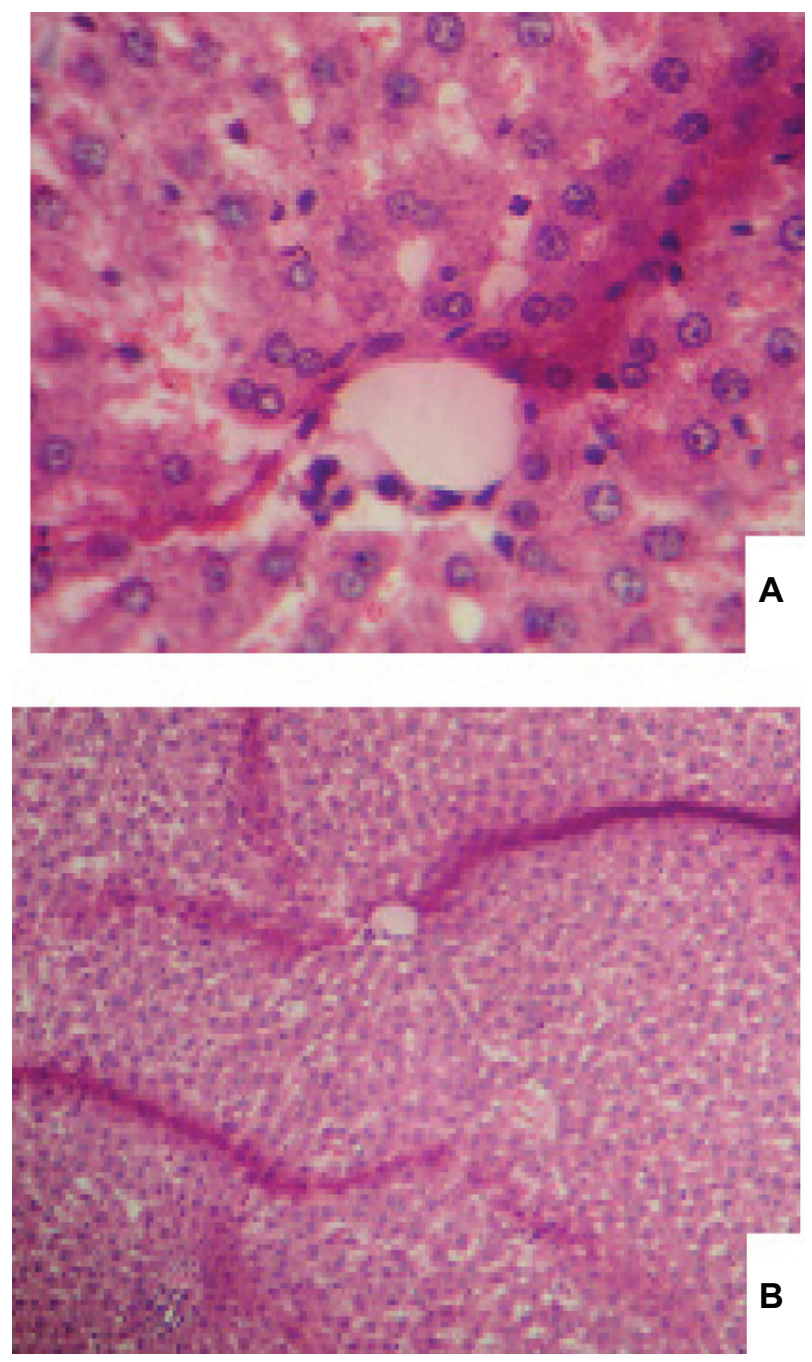

Figure I The figures of the liver tissue injected with the reduced size acetaminophen, (A) with high resolution, and (B) with low resolution. 

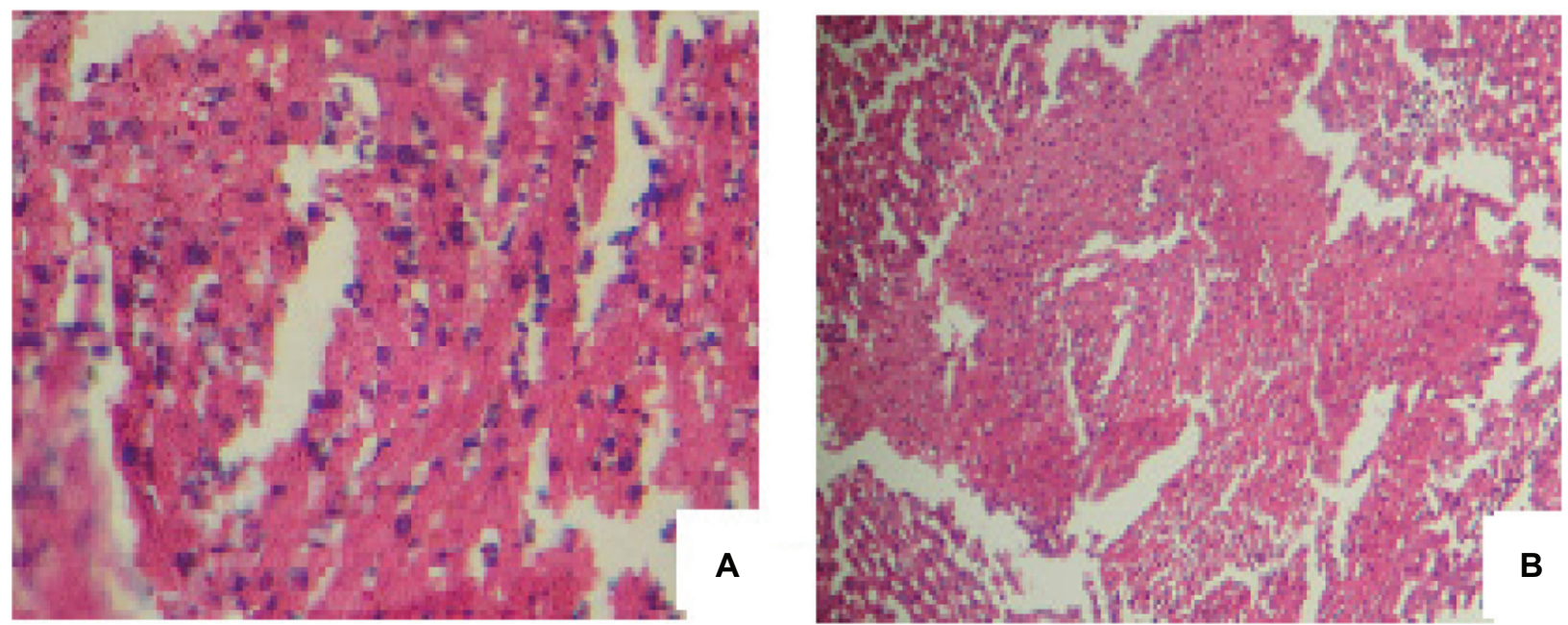

Figure 2 Images of the liver tissue injected with the normal size acetaminophen, (A) with high resolution, and (B) with low resolution.

The tissue samples in enzymatic investigations illustrated that the results in Table 4 were related to the intravenous injection of the powders and the enzymatic activation exhibited no change in the quantity of ALP and AST with the reduced and normal size of the injected drug. On the other hand, the activation related to the quantity ALT demonstrated a reduction for the reduced size powders. The statistical investigation of the Student's $t$-test made it clear that the intravenous injection of the reduced size drug samples changed the enzymatic ALT quantity. This observation was confirmed by the results displayed in Table $4(P<0.05)$ and revealed the ALT specificity for the liver enzyme. This may be because these enzymes are not only found in the liver, but also in different places in the body. The toxicity of the injected samples with the reduced size was (in pathological figures and ALT enzyme) lower than that in the normal sized samples.

Table 4 The given statistical results, estimated from the difference between the control, the normal, and the reduced size acetaminophen in three enzymes

\begin{tabular}{|c|c|c|c|c|c|}
\hline $\begin{array}{l}\text { Dependent } \\
\text { variable }\end{array}$ & (I) Drug & (J) Drug & Mean difference (I-J) & Std. error & Sig. \\
\hline \multirow[t]{6}{*}{$\overline{\text { GOT }}$} & acetaminophen & nano & -11.052500 & 8.6227438 & 0.421 \\
\hline & & vehicle & $51.720357^{*}$ & $9.184 \mid 483$ & 0000 \\
\hline & nano & acetaminophen & 11.052500 & 8.6227438 & 0.421 \\
\hline & & vehicle & $62.772857^{*}$ & 8.9428715 & 0.000 \\
\hline & vehicle & acetaminophen & $-51.720357^{*}$ & $9.184 \mid 483$ & 0.000 \\
\hline & & nano & $-62.772857^{*}$ & 8.9428715 & 0.000 \\
\hline \multirow[t]{6}{*}{ GPT } & acetaminophen & nano & $\left.|3.5986|\right|^{*}$ & 4.8854754 & 0.029 \\
\hline & & vehicle & $27.627500^{*}$ & 5.2035560 & 0.000 \\
\hline & nano & acetaminophen & $-\left.|3.5986|\right|^{*}$ & 4.8854754 & 0.029 \\
\hline & & vehicle & |4.028889* & 5.0668534 & 0.030 \\
\hline & vehicle & acetaminophen & $-27.627500^{*}$ & 5.2035560 & 0.000 \\
\hline & & nano & $-14.028889^{*}$ & 5,0668534 & 0.030 \\
\hline \multirow[t]{6}{*}{ ALP } & acetaminophen & nano & -22.217917 & 13.586678 & 0.253 \\
\hline & & vehicle & 9.204464 & $|4.47| 27 \mid$ & 0.802 \\
\hline & nano & acetaminophen & 22.217917 & 13.586678 & 0.253 \\
\hline & & vehicle & 31.422381 & 14.091096 & 0.089 \\
\hline & vehicle & acetaminophen & -9.204464 & |4.47|27| & 0.802 \\
\hline & & nano & -31.422381 & 14.091096 & 0.089 \\
\hline
\end{tabular}

Abbreviations: ALP, alkaline phosphatase; ALT, alanine aminotransferase; AST, aspartate aminotransferase. 
ALP

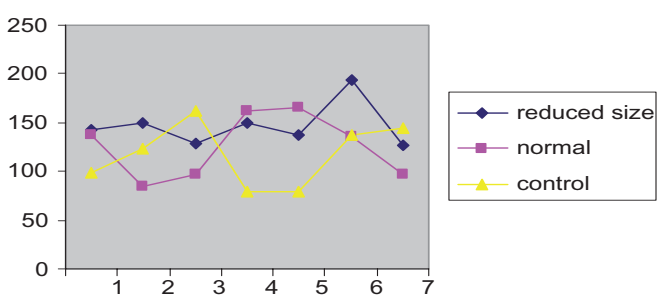

AST

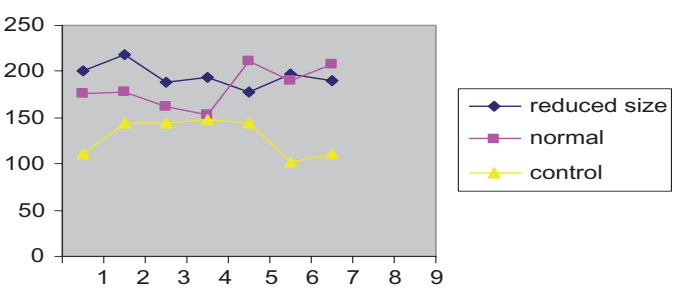

ALT

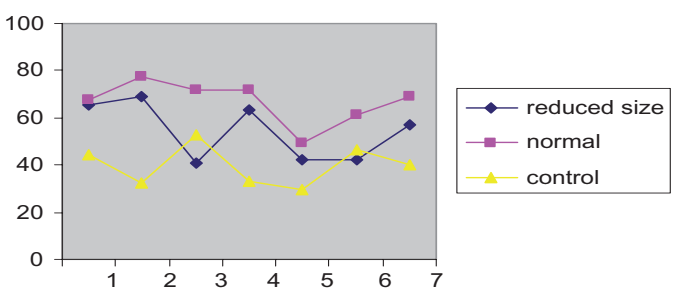

Figure 3 The amount of the delivered enzymes related to the blood circulation for different enzymes and the difference between three types of injection materials.

Abbreviations: ALP, alkaline phosphatase; ALT, alanine aminotransferase; AST, aspartate aminotransferase.

Nevertheless, further investigation should be carried out in this field. For instance using various animals with a longer follow-up time after drug injection. Kinetic effects may mean increasing the connection among the reduced size acetaminophen particles and plasma proteins for slower drug delivery to the liver system. The appropriate time for eliminating toxic metabolism, absorption effects of reducing the activated particle size on liver-conjugated systems like glucuronide, sulfate increases, and toxic metabolite production will be reduced.

\section{Disclosures}

The authors report no conflicts of interest in this work.

\section{References}

1. Chow GM, Noskova NI. Nanostructured Materials: Science and technology. Philadelphia, PA: Springer; 1997.

2. Brock JR Nanostructured Materials: Science and technology. Philadelphia, PA: Kluwer Acad; 1997.

3. Lee J. Drug nano-and microparticles processed into solid dosage forms: Physical properties. J Pharm Sci. 2003;92(10):2057-2068.

4. Rabinow BE. Nanosuspensions in drug delivery. Nature Rev. 2004;3:785-796.

5. Ventosa N, Sala S, Veciana J. DELOS Process: A crystallization technique using compressed fluids. 1 comparsion to the gas crystallization methods. J Supercrit Fluids. 2003;26:33-45.

6. Suryanarayana C. Mechanical Alloying and Milling. Boca Raton, FL CRC Press; 2001.

7. Hüttenrauch R, Fricke $S$, Zielke P. Mechanical activation of pharmaceutical systems. Pharm Res. 1985;2:302-306.

8. Brodka-Pfeiffer K, Langguth P, Grass P, Haüsler H. Influence of mechanical activation on the physical stability of salbutamol sulphate. Eur J Pharm Biopharm. 2003;56:393-400.

9. Sweetman SC. The Complete Drug Reference. 34th ed. London, UK: Pharmaceutical Press; 2005.

10. Rinaki E, Valsami G, Macheras P. Quantitative biopharmaceutics classification system: The central role of dose/solubility ratio. Pharm Res. 2003;20:1917-1925.

11. Ellen Horn MJ, Barceloux FG. Medical toxicology, diagnosis and teratment of human poisoning. Am J Hosp Pharm. 1987;44:549-556.

12. Forrest JA, Adriaenssens P, Finlayson NC, Prescott LF. Paracetamol metabolism in chronic liver disease. Eur J Clin Pharmacol. 1979;15:427-431.

13. Numata K, Kubo M, Watanabe H, et al. Overexpression of suppressor of cytokine signaling- 3 in T cells exacerbates acetaminophen-induced hepatotoxicity. J Immunol. 2007;178:3777-3785.

14. James LP, Mayeux PR, Hinson JA. Acetaminophen-induced hepatoxicity. J Toxicol Sci. 2003;31:1499-1506.
International Journal of Nanomedicine

\section{Publish your work in this journal}

The International Journal of Nanomedicine is an international, peerreviewed journal focusing on the application of nanotechnology in diagnostics, therapeutics, and drug delivery systems throughou the biomedical field. This journal is indexed on PubMed Central, MedLine, CAS, SciSearch $\AA$, Current Contents $₫ /$ Clinical Medicine,

\section{Dovepress}

Journal Citation Reports/Science Edition, EMBase, Scopus and the Elsevier Bibliographic databases. The manuscript management system is completely online and includes a very quick and fair peer-review system, which is all easy to use. Visit http://www.dovepress.com/ testimonials.php to read real quotes from published authors. 